\author{
Journal of Sustainability Business Research (JSBR) \\ Vol-1,Issue-1,Desember (JSBR) \\ E-ISSN: 2746-8607
}

http://jurnal.unipasby.ac.id/index.php/jsbr

\title{
PENGARUH RISIKO LIKUIDITAS DAN PERTUMBUHAN PENJUALAN TERHADAP HARGA SAHAM PADA PERUSAHAAN PROPERTI DAN REAL ESTATE
}

\author{
Nur Maulida Chasanah ${ }^{1}$, Aji Prasetyo² \\ Universitas PGRI Adi Buana Surabaya ${ }^{1,2}$ \\ maulida.nur94@gmail.com¹ , ajiprasetyo@unipasby.ac.id²
}

\begin{abstract}
Saham termasuk dalam jenis investasi di pasar modal yang digunakan oleh banyak investor, maka investor perlu untuk mengamati harga saham dari suatu perusahaan sebelum memulai investasi. Variabel yang digunakan untuk mengukur harga saham menggunakan Risiko Likuiditas dan Pertumbuhan Penjualan. Penelitian ini mempunyai tujuan yaitu untuk mengetahui apakah ada pengaruh antara variabel bebas terhadap variabel terikat yang dipilih dalam penelitian ini. Dokumentasi adalah teknik yang dipilih untuk pengumpulan data. Teknik untuk mengalisis data dalam penelitian ini menerapkan analisis regresi linier berganda, uji asumsi klasik, serta uji t dan uji-f. Hasil uji-t variabel Risiko Likuiditas memperoleh nilai 0,009 karena $(0,009<0,05)$ maka Risiko Likuiditas memengaruhi harga saham. Hasil uji t variabel Pertumbuhan Penjualan memperoleh nilai 0,762 karena $(0,762>0,05)$ maka Pertumbuhan Penjualan tidak memengaruhi harga saham. Sedangkan untuk hasil uji-f memperoleh nilai 0,019 karena $(0,019<0,05)$ maka variabel Risiko Likuiditas dan Pertumbuhan Penjualan memengaruhi harga saham secara bersama-sama.
\end{abstract}

Kata Kunci : Harga Saham, Risiko Likuiditas, Pertumbuhan Penjualan

\begin{abstract}
Stocks are included in the types of investments in the capital market that are used by many investors, so investors need to observe the stock price of a company before starting an investment. The variable used to measure stock prices uses Liquidity Risk and Sales Growth. The purpose of this research is to find out whether there are differences between the independent variables and the variables chosen in this study. Documentatiton is the technique chosen for data collection. Data analysis techniques in this study used multiple linear regression analysis, the classic assumption test, as well as the $t$ test and $f$-test. Liquidity risk variable $t$-test result obtained value of 0.009 because $(0.009<0.05)$, then Liquidity Risk affects the stock price. Sales Growth variable t-test result obtained value of 0.762 because $(0.762>0.05)$ then Sales Growth has no effect on stock prices. While for the f-test resuls obtained a value of 0,019 because $(0,019<0,05)$ then the liquidity risk and sales growth variables affect stock prices together.
\end{abstract}

Keywords: Stock Prices, Liquidity Risk, Sales Growth

\section{PENDAHULUAN}

Pasar modal dapat dijadikan sebagai media untuk mempertemukan antara emiten dan investor untuk memperoleh modal. Perusahaan yang memerlukan modal atau disebut emiten adalah penjual dalam kegiatan di pasar modal, pihak yang membeli modal disebut pembeli atau investor, investor melakukan kegiatan membeli modal di suatu perusahaan adalah untuk mendapatkan keuntungan. Dilihat dari segi waktu jenis investasi di pasar modal termasuk dalam modal jangka panjang. Hal ini dinilai menguntungkan bagi perusahaan karena tergolong masa pengembaliannya yang panjang, bagi investor hal ini juga dinilai menguntungkan karena investor dapat menginvestasikan dalam waktu yang 


\section{Journal of Sustainability Business Research (JSBR) \\ Vol-1,Issue-1,Desember (JSBR) \\ E-ISSN: 2746-8607}

http://jurnal.unipasby.ac.id/index.php/jsbr

lama. Negara Indonesia memiliki pasar modal dikenal dengan Bursa Efek Indonesia (BEI) atau Indonesian Stock Exchange (IDX). Bursa Efek Indonesia (BEI) ini sangat membantu untuk masayarakat umum yang ingin menginvestasikan sebagaian dari hartanya dan juga menjadi sarana tempat untuk perusahaan yang go public mencari tambahan modalnya. Maka Bursa Efek Indonesia (BEI) mempunyai peran penting untuk mengembangkan ekonomi di negara

Menurut Prasetyo, Aji (2019) "Suatu nilai atau pertanda kepemilikan atas modal keuangan milik perorangan maupun badan di perusahaan disebut dengan saham". Harga saham di nilai penting pada kalangan investor karena harga saham berakibat pada ekonomi. Harga saham pasti mengalami fluktuasi yang akan berdampak pada berubahnya nilai, sehingga kesempatan investor untuk memperoleh keuntungan di masa mendatang akan ikut berubah. Dengan demikian harga saham sangat menentukan nilai perusahaan yang terdapat di pasar modal.

Dalam membeli saham investor selalu mengidentifikasi risikonya, salah satu risiko yang penting yaitu risiko likuiditas. "Perusahaan di nilai mampu dalam membayar kewajiban utang jangka pendeknya adalah pengertian Likuiditas" Menurut Hery (2017:284). Perusahaan yang memiliki kemampuan dalam melunasi semua kewajibanya dengan tepat waktu akan lebih diyakini oleh investor karena investor menganggap bahwa perusahaan tersebut likuid. Indikator yang di pilih untuk melakukan pengukuran likuiditas adalah Rasio Lancar (Current Ratio). Cara menghitung Current Ratio lebih mendasar bagi perusahaan, maka lebih tepat untuk dasar perhitungan dari likuiditas.

Pertumbuhan penjualan menggambarkan bahwa investasi di periode tahun lalu di nilai berhasil serta bisa digunakan sebagai estimasi pada periode selanjutnya. Penjualan yang terus-menerus meningkat dari periode ke periode mengakibatkan keuntungan perusahaan akan meningkat. Dengan meningkatnya keuntungan perusahaan maka investor akan memilih menanam saham di perusahaan tersebut karena perusahaan dinilai mempunyai kinerja yang baik.

Sesuai uraian yang telah dijabarkan, dapat ditemukan rumusan masalah yaitu:

1. Apakah ada pengaruh antara risiko lukuiditas terhadap harga saham?

2. Apakah ada pengaruh antara pertumbuhan penjualan terhadap harga saham ?

3. Apakah ada pengaruh antara risiko lukuiditas dan pertumbuhan penjualan terhadap harga saham ?

Ada pula tujuan yang diinginkan pada penelitian kali ini adalah :

1. Untuk mengetahui pengaruh risiko lukuiditas terhadap harga saham.

2. Untuk mengetahui pengaruh pertumbuhan penjualan terhadap harga saham.

3. Untuk mengetahui pengaruh secara signifikan risiko lukuiditas dan pertumbuhan penjualan terhadap harga saham.

Penelitian Terdahulu

Adapun Penelitian sebelumnya yang dipilih untuk gambaran penelitian ini meliputi : (1) Maryanti (2016), memperoleh hasil yaitu pertumbuhan penjualan tidak memengaruhi struktur modal secara signifikan. (2) Bailia, Tommy, \& Baramulli (2016), dihasilkan bahwa pertumbuhan penjualan tidak memengaruhi harga saham secara parsial. (3) Nandia (2016), memperoleh hasil yaitu pertumbuhan 


\section{Journal of Sustainability Business Research (JSBR) \\ Vol-1,Issue-1,Desember (JSBR) \\ E-ISSN: 2746-8607}

http://jurnal.unipasby.ac.id/index.php/jsbr

penjualan berpengaruh terhadap struktur keuangan dengan positif. (4) Suweta \& Dewi (2016), memperoleh hasil yaitu pertumbuhan penjualan memengaruhi struktur modal secara positif dan signifikan. (5) Lestari, Andini, \& Abrar (2016), memperoleh hasil likuiditas tidak memengaruhi return saham. (6) Hanie \& Saifi (2018), dengan hasil penelitian variabel Current Ratio memengaruhi harga saham secara dominan daripada variabel lain yang digunakan.(7) Akram (2014) memperoleh hasil bahwa likuiditas tidak memengaruhi return saham. (8) Kamau \& Njeru (2016) menunjukkan hasil penelitian bahwa risiko operasional, pasar dan risiko likiditas memiliki efek negatif atau tidak berpengaruh terhadap kinerja keuangan.

\section{Teori Signal}

Landasan teori sebagai landasan dasar yaitu Signaling Theory (teori signal). Menurut Miller \& Rock (2007) "Model teori signal ini terjadi ketika diketahui peluang investasi lebih rendah daripada investasi riil, model ini juga menjamin kekurangan insentif investasi dengan mengasumsikan dari fungsi peluang investasi sehingga model ini adalah bersifat terbuka artinya investormengetahui informasi". Dalam teori ini manajer akan memberikan signal kepada investor atas keadaan perusahaan saat ini melalui laporan keuangan perusahaan.

\section{Harga Saham}

Harga saham menggambarkan segala informasi atas masalah di pasar modal. Dengan kinerja perusahaan yang baik, perusahaan mendapatkan citra baik di kalangan investor. Harga saham juga memberikan keuntungan bagi investor dan perusahaan. Perusahaan mendapat keuntungan berupa reputasi di kalangan investor. Sebaliknya bagi investor akan memperoleh keuntungan dari bagi hasil saham yang di belinya.

\section{Risiko Likuiditas}

Menurut Kasidi (2010:4) "Risiko merupakan suatu keadaan yang memungkinkan ketika harapan tidak sesuai dengan rencana yang dapat membuat rugi". Rasio yang menjadi bagian untuk menunjukkan bahwa perusahaan mempunyai kemampuan untuk melunasi pasiva yang sifatnya pendek secara disiplin" adalah penjabaran likuiditas menurut Sulindawati et al., 2017:135)

Salah satu dasar perhitungan yang tepat untuk menghitung nilai likuiditas yaitu dengan rasio lancar (current ratio), karena memberikan indeks terbaik atas aktiva relatif lebih cepat di uangkan atau diubah menjadi kas yang dapat menutupi besarnya utang jangka pendek.

\section{Pertumbuhan Penjualan}

Keberhasilan perusahaan dapat digambarkan dengan pertumbuhan penjualannya.Dengan nilai pertumbuhan yang semakin meningkat setiap periodenya maka dapat memotivasi untuk penjualan periode selanjutnya. Menurut Swastha, (2011:203) "Perusahaan akan melakukan penawaran atas produknya sebelum menjualnya, maka penjualan adalah salah satu yang dapat mencerminkan kesuksesan usaha tersebut". 


\section{Journal of Sustainability Business Research (JSBR) \\ Vol-1,Issue-1,Desember (JSBR) \\ E-ISSN: 2746-8607}

http://jurnal.unipasby.ac.id/index.php/jsbr

\section{KERANGKA KONSEPTUAL}

Kerangka konseptual penelitian ini diterapkan untuk mempermudah arah penelitian, seperti yang di gambarkan dibawah ini :

Catatan

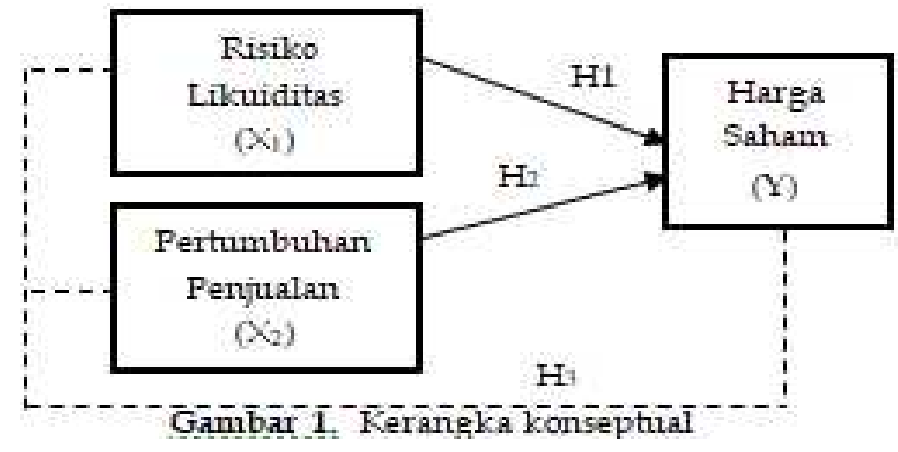

$\longrightarrow$ =Pengaruh secara parsial

$--\rightarrow$ = Pengaruh secara simultan

\section{HIPOTESIS}

Dari penjabaran yang telah dikemukakan, hipotesis penelitian ini:

$\mathrm{H} 1$ = Ada pengaruh risiko likuiditas terhadap harga saham.

$\mathrm{H} 2$ = Ada pengaruh pertumbuhan penjualan terhadap harga saham.

$\mathrm{H} 3$ = Ada pengaruh risiko likuiditas dan pertumbuhan penjualan terhadap harga saham secara signifikan.

\section{METODE}

Metode yang dipilih adalah metode kuantitatif. Populasinya adalah perusahaan properti dan real estate yang terdaftar di BEI. Sedangkan sampelnya yaitu laporan keuangan perusahaan properti dan real estate yang terdaftar di Bursa Efek Indonesia pada tahun 2014-2018, dengan kriteria adalah:

Tabol1, Kriteria Pengambilan Sampel

\begin{tabular}{|c|c|c|}
\hline No & Kritcrla Pcmillahn Sampcl & Jumian \\
\hline 1 & $\begin{array}{l}\text { Perlusahaan Fropperti dian Real Fsmata } \\
\text { lcrutuntur di BEl }\end{array}$ & 48 \\
\hline \multirow[t]{2}{*}{2} & Tersedianya laporan keuangan & 12 \\
\hline & $\begin{array}{l}\text { tahunan perusahaan properti dan Real } \\
\text { Lstete di LLI peda tenun } 2014-2018\end{array}$ & \\
\hline \multirow[t]{2}{*}{3} & $\begin{array}{l}\text { Perusatiadr Pruperti dari Real Eslate } \\
\text { lernassuk perusahadi lerlingyi seklur } \\
\text { properti Real Estate di Indonesia }\end{array}$ & 6 \\
\hline & Sampel yang dipilin & is \\
\hline
\end{tabular}

Variabel bebas yang digunakan yaitu risiko likuiditas $\left(X_{1}\right)$ dan pertumbuhan penjualan $\left(X_{2}\right)$. Sedangkan harga saham $(Y)$ adalah variabel terikat. Definisi operasional variabel adalah : 


\section{Journal of Sustainability Business Research (JSBR) \\ Vol-1,Issue-1,Desember (JSBR) \\ E-ISSN: 2746-8607}

http://jurnal.unipasby.ac.id/index.php/jsbr

1. Risiko Likuiditas

Perusahaan di nilai mampu dalam membayar semua utang lancar secara tepat waktu adalah pengertian dari likuiditas. Pengukuran likuiditas yang digunakan adalah rasio lancar (current ratio), berarti menganalisis perbandingan dari aktiva lancar perusahaan dengan pasiva lancar.

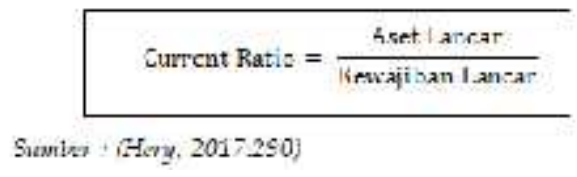

2. Pertumbuhan Penjualan

Kondisi penjualan suatu perusahaan yang mengalami kenaikan di setiap tahun merupakan arti dari pertumbuhan penjualan. Dengan mengalami kenaikan setiap tahun berarti perusahaan dapat menambah kegiatan produksinya. Salah satu hal yang bisa dijadikan sebagai pengukur pertumbuhan perusahaan adalah pertumbuhan penjualannya. Dengan penjualan yang terus meningkat perusahaan berkembang dengan pesat yang akan memengaruhi nilai perusahaan.

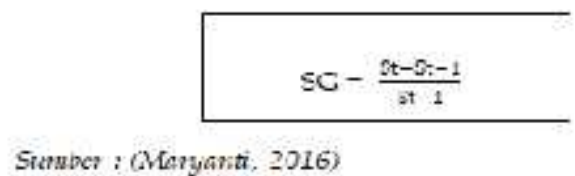

3. Harga Saham

harga saham dapat berubah kapan saja bisa naik maupun turun karena pelaku pasar yaitu investor dan emiten serta karena penawaran permintaan saham. Harga yang digunakan adalah penutupan akhir tahun yang berarti berarkhirnya kinerja tahun tersebut. Kinerja perusahaan yang baik akan membuat harga sahamnya meningkat.

Pengumpulan Data

Dokumentasi adalah yang dipilih untuk membantu dalam mengumpulkan data, yaitu berbentuk laporan keuangan tahunan.

Teknik Analisis Data

Teknis analisis data adalah analisis statistik. Program SPSS versi 24.0 dipilih untuk membantu dalam menganalisa, menerapkan analisis regresi linier berganda dan uji hipotesis.

\section{HASIL}

Uji Asumsi Klasik

Ujinormalitas dengan menggunakan uji statistic non-parametrik Kolmogorov-Smirnov (K-S) memperoleh angka signifikan 0,200, angka tersebut diatas 0,05 atau $(0,200>0,05)$ data juga menyebar dan searah garis diagonal. Dapat diartikan semua data berdistribusi dengan normal. Berikut hasil uji statistic non-parametrik Kolmogorov-Smirnov : 


\section{Journal of Sustainability Business Research (JSBR) \\ Vol-1,Issue-1,Desember (JSBR) \\ E-ISSN: 2746-8607}

http://jurnal.unipasby.ac.id/index.php/jsbr

Tabel 2. Hasil Uji Normalitas

\begin{tabular}{|l|l|l|}
\hline \multicolumn{3}{|l|}{ One-Sample Kolmogaror-Smimov Test } \\
\hline Unstandaryized & $\mathrm{N}$ & $=30$ \\
\hline Residual & Test Statistic & $=0,113$ \\
\cline { 2 - 3 } & $\begin{array}{l}\text { Asymp. Sig. } \\
\text { (2tailed) }\end{array}$ & $=0,200$ \\
\hline Sumbe:Lampiran Output SP3S (data \\
diolah)
\end{tabular}

Pada uji multikolinearitas dinilai melihat VIF dan angka tolerance. Hasil pengujian ini menunjukkan nilai VIF = 1,073 (<10) dan tolerance sebesar 0,932 mendekati 1. Diartikan tidak terjadi hubungan diantara variabel bebas. Berikut akan disajikan hasil dari uji multikolinearitas :

Tabel 3. Hasil Uji Multikolinearites

\begin{tabular}{l|l|l}
\hline \multicolumn{3}{|c|}{ Collinearity Statistics } \\
\hline & Tolerance & VIF \\
\hline$x_{1}$ & 0932 & 1,073 \\
\hline$x_{2}$ & 0932 & 1,073 \\
\hline \multicolumn{3}{|c|}{ Sumber LampiranOutut SPSS 24.0 (cata } \\
ciolah)
\end{tabular}

Selanjutnya uji autokorelasi yang menerapkan uji Run Test. Dari hasil ini di peroleh nilai Runt Test 0,577, nilai tersebut diatas 0,05 atau $(0,577>0,05)$. Maka diartikan bahwa data yang dipilih adalah random yang berarti bebas masalah autokorelasi terhadap data yang sedang diuji. Berikut ini adalah sajian dari uji tersebut :

Tabel 4. Hasil Uji Autokorelasi

\begin{tabular}{|l|l|l|}
\hline \multicolumn{2}{|l|}{ Run Test } & $=30$ \\
\hline Unstandardized & $\mathrm{N}$ & $=0,577$ \\
\hline Residual & $\begin{array}{l}\text { Asymp. Sig. } \\
\text { (2-tailed) }\end{array}$ & \\
\hline
\end{tabular}

Sumber-I ampiran Dutput SPSS240 (dara diolah) 


\section{Journal of Sustainability Business Research (JSBR) \\ Vol-1,Issue-1,Desember (JSBR) \\ E-ISSN: 2746-8607}

http://jurnal.unipasby.ac.id/index.php/jsbr

Uji Heteroskedastisitas dilakukan menggunakan grafik scatterplot. Menurut hasil grafik Scatterplot digambarkan plot atau titik-titik menyeluruh dengan random dan tidak berbentuk bangun yang nyata. Dapat diartikan dalam penelitian ini tidak ada masalah dari heteroskedastisitas. Hasil pengujian tersebut adalah :

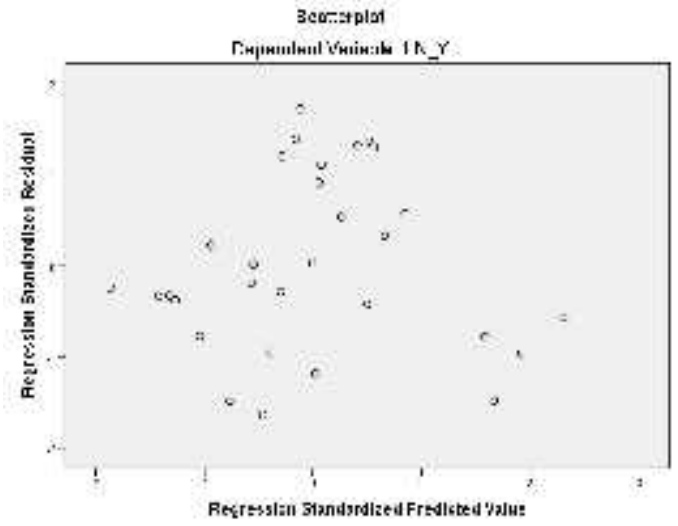

Gambar 2. Scatterplot

Analisis Regresi Linier Berganda

Diterapkan untuk mengetahui ada atau tidak keterkaitan antar vaiabel serta dapat menentukan nilai ketergantungan variabel bebas yaitu risiko likuiditas (X1), pertumbuhan penjualan (X2), dengan variabel terikat yakni harga saham $(Y)$.

Pengujian ini memperoleh hasil sebagai berikut :

Tabel 5. Hasil Uji Reqresi Linier Berganda

\begin{tabular}{|c|c|c|c|c|c|}
\hline \multirow[b]{2}{*}{ Model } & \multicolumn{2}{|c|}{$\begin{array}{l}\text { Unstandard } \\
\text { Coetticients }\end{array}$} & \multirow{2}{*}{$\begin{array}{l}\begin{array}{l}\text { Standard } \\
\text { Coetticiens }\end{array} \\
\text { Beta }\end{array}$} & \multirow[b]{2}{*}{$t$} & \multirow[b]{2}{*}{ Sig: } \\
\hline & B & Std. Error & & & \\
\hline (Const) & 6,260 &, 281 & & 22,253 &, 000 \\
\hline$L N \_\times 1$ & .551 & .195 & .487 & 2.830 & .009 \\
\hline$L_{1} X_{2}$ &, 029 &, 085 &, 053 &, 306 & 762 \\
\hline
\end{tabular}

Di ambil dari tabel diatas, penulisan persamaan regresi dapat dituliskan yaitu:

$$
Y=6,260+0,551 X 1+0,029 \times 2+e
$$

Uji t diterapkan untuk mengetahui berapa besar yang memengaruhi antara variabel bebas dengan variabel terikat secara individual.

Sesuai tabel 5 ditemukan hasil untuk risiko likuiditas sebagai variabel pertama memperoleh hasil t-hitung senilai 2,830 tingkat signifikansi risiko likuiditas senilai 0,009. Dapat disimpulkan bahwa $(0,009<0,05)$, yang berarti risiko likuiditas $(X 1)$ memengaruhi harga saham $(Y)$ secara parsial. 


\section{Journal of Sustainability Business Research (JSBR) \\ Vol-1,Issue-1,Desember (JSBR) \\ E-ISSN: 2746-8607}

http://jurnal.unipasby.ac.id/index.php/jsbr

Penyebabnya adalah ketika nilai risiko likuiditas meningkat berdampak pada harga saham yang meningkat pula, seperti yang terlihat pada sampel penelitian ini. Banyak investor menilai bahwa semakin perusahaan memiliki kemampuan dalam membayar kewajibannya maka deviden yang akan diperoleh oleh investor bertambah pula. Sehingga daya beli saham mengalami kenaikan yang mengakibatkan naiknya harga saham.

Variabel kedua yaitu pertumbuhan penjualan. Hasil dari uji-t diatas diperoleh nilai $t_{\text {hitung }}=0,306$ tingkat signifikansi pertumbuhan penjualan sebesar 0,762 sehingga $(0,762>0,05)$. Hasil tersebut menunjukkan variabel pertumbuhan penjualan (X2) tidak memengaruhi harga saham (Y). Hal ini terjadi sebab nilai pertumbuhan penjualan yang mengalami peningkatan berdampak pula pada meningkatnya biaya yang dibayar oleh perusahaan, maka meningkatnya pertumbuhan penjualan tidak menjamin naiknya pendapatan dan laba suatu perusahaan. Investor menilai suatu perusahaan mempunyai nilai yang baik bukan hanya dilihat dari pertumbuhan penjualannya saja melainkan banyak faktor, seperti kemampuan dalam mengolah dana.

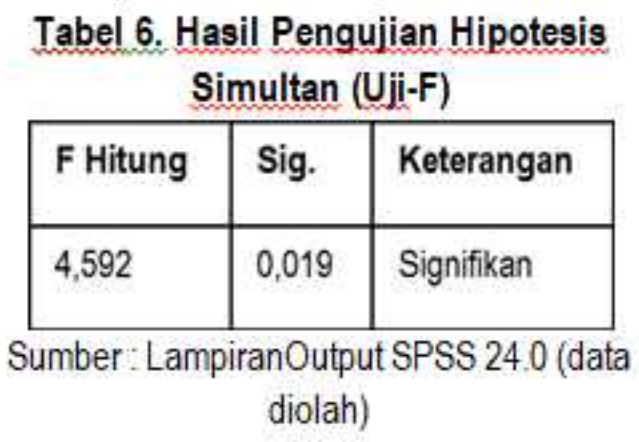

Selanjutnya pengujian Uji F. diperoleh nilai thitung $=4,592$ nilai signifikan adalah 0,019, sehingga $(0,019<0,05)$. Diartikan bahwa kedua variiabel bebs yaitu pertmbuhan penjualn $(x 1)$, risiko liikuiditas (x2) secara simultan memengaruhi harga saham $(\mathrm{Y})$, sehingga untuk $\mathrm{H} 3$ pada penelitian ini diterima.

\section{SIMPULAN}

Kesimpulan dari hasil pengujian dari yang dilakukan adalah:

1. Hasil Uji-t di peroleh variabel Risiko Likuiditas $\left(\mathrm{x}_{1}\right)$ memengaruhi harga saham.

2. Pada hasil Uji-t didapatkan variabel Peertumbuhan Penjualan $\left(\mathrm{x}_{2}\right)$ tidak memengaruhi harga saham secara signfikan.

3. Hasil Uji-F Resiko Likuiditas $\left(\mathrm{x}_{1}\right)$ dan Pertumbuhan Penjualan Penjualan $\left(\mathrm{x}_{2}\right)$ memengaruhi harga saham secara bersama-sama.

\section{IMPLIKASI}




\section{Journal of Sustainability Business Research (JSBR) \\ Vol-1,Issue-1,Desember (JSBR) \\ E-ISSN: 2746-8607}

http://jurnal.unipasby.ac.id/index.php/jsbr

Dari analisa yang telah dilakukan, telah membuktikan bahwa terdapat pengaruh risiko likuiditas dan pertmbuhan penjualan terhadap harga saaham. Didapatkan bahwa risiko likuiditas memengaruhi harga saham secara positif, sehingga untuk variabel risiko likuiditas bisa menjadi tolak ukur untuk memastikan harga saham. Variabel yang kedua yaitu pertumbuhan penjualan, dengan hasil mengatakan pertumbuhn penjualan tidak memengaruhi harga saham, jadi untuk variabel pertumbuhan penjualan kurang kuat jika dijadikan sebagai acuam dalam menentukan harga saham. Bagi investor harus lebih menganalisa tolak ukur dari harga saham. Sedangkan bagi perusahaan dapat mempertahankan serta meningkatkan tingkat risiko likuiditas dengan pengukuran current ratio ini, variabel tersebut dinilai lebih baik dengan membandingkan aktiva dan utang lancar perusahaan karena dengan menganalisis risiko likuiditas suatu perusahaan dapat mengetahui likuidnya perusahaan dalam membayar kewajiban lancarnya, serta juga perlu memperhatikan hal-hal yang dapat mengembangkan harga saham.

\section{KETERBATASAN PENELITIAN}

Keterbatasan Penelitian ini yaitu hanya memakai satu pengukuran untuk menghitung besarnya risiko likuiditas suatu perusahaan sebagai faktor internal yang menjadi acuan untuk menilai harga saham. Sehingga bagi peneliti selanjutnya sebaiknya menggunakan lebih banyak faktor internal lainnya sebagai variabel independen dan bisa memilih sampel lain yang telah dipilih untuk penelitian ini atau menambah jumlah sampel penelitian agar cakupan yang dituju lebih luas.

\section{DAFTAR PUSTAKA}

Akram, N. (2014). The Effect of Liquidity on Stock Returns : An Evidence From Pakistan. 16(2), 6669.

Bailia, F. F. W., Tommy, P., \& Baramulli, D. N. (2016). Pengaruh Pertumbuhan Penjualan, Dividend Payout Ratio Dan Debt To Equity Ratio Terhadap Harga Saham Pada Perusahaan Property Di Bursa Efek Indonesia. Jurnal Berkala IImiah Efisiensi, 16(3), 270-278.

Darmaji, T., \& Fakhruddin. (2012). Pasar Modal di Indonesia (Edisi Keti). Jakarta: Salemba Empat. Darsono, \& Rahman, R. E. (2018). Pasar Valuta Asing. Depok: PT Raja Grafindo Persada.

Ghozali, I. (2013). Aplikasi Analisis Multivariate dengan Program SPSS (Edisi Ketu). Semarang: Badan Penerbit Universitas Diponegoro.

Gunawan, R. M. B. (2016). Good Governance, Risk Management, and Compliance (Cetakan ke). Jakarta: PT Raja Grafindo Persada.

Hanie, U. P., \& Saifi, M. (2018). Pengaruh Rasio Likuiditas dan Rasio Leverage Terhadap Harga Saham Studi Pada Perusahaan Indeks LQ45 Periode 2014-2016. Jurnal Administrasi Bisnis (JAB), 58(1), 95-102.

Kamau, F., \& Njeru, A. (2016). Effect of Liquidity Risk on Financial Performance of Insurance Companies Listed at the Nairobi Securities Exchange. 5(10), 867-872. https://doi.org/10.21275/ART20162288

Kasidi. (2010). Manajemen Risiko. Bogor: Ghalia Indonesia. 


\section{Journal of Sustainability Business Research (JSBR) \\ Vol-1,Issue-1,Desember (JSBR)}

E-ISSN: 2746-8607

http://jurnal.unipasby.ac.id/index.php/jsbr

Lestari, K., Andini, R., \& Abrar, O. (2016). Analisis Likuiditas, Leverage, Profitabilitas, Aktivitas, Ukuran

Perusahaan dan penilaian Pasar Terhadap Return Saham (Pada Perusahaan Real Estate dan Property di BEI) Periode Tahun 2009-2014. Journal of Accounting, Vol. 2(2), 1-19.

Maryanti, E. (2016). Analisis Profitabilitas, Pertumbuhan Perusahaan, Pertumbuhan Penjualan dan

Struktur Aktiva Terhadap Struktur Modal Pada Perusahaan Sektor Industri Barang Konsumsi Yang Terdaftar Di Bursa Efek Indonesia. Riset Akuntansi Dan Keuangan Indonesia, 1(2), 143151. https://doi.org/10.23917/reaksi.v1i2.2730

Meythi, En, T. K., \& Rusli, L. (2011). Pengaruh Likuiditas dan Profitabilitas Terhadap Harga Saham Perusahaan Manufaktur yang Terdaftar di Bursa Efek Indonesia. Jurnal Bisnis Manajemen Dan Ekonom, 10(2).

Miller, M. H., \& Rock, K. (2007). Dividend Policy under Asymmetric Information. 40(4), 1031-1051.

Prasetyo, Aji. (2019). Wakaf Saham Dalam eningkatkan Investasi Saham Syariah Di Indonesia. Majalah Ekonomi. 